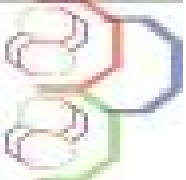

Journal of Applied Biosciences 82:7372 - 7378

ISSN 1997-5902

\title{
Density, Shatter index, and Combustion properties of briquettes produced from groundnut shells, rice husks and saw dust of Daniellia oliveri
}

\author{
Tembe, E.T., Otache, P.O. and *Ekhuemelo, D.O. \\ Department of Forest Production and Products, University of Agriculture Makurdi \\ *Corresponding author: doekhuemelo@yahoo.com
}

Original submitted in on $12^{\text {th }}$ August 2014. Published online at www.m.elewa.org on $31^{\text {st }}$ October 2014. http://dx.doi.org/10.4314/jab.v82i1.7

\begin{abstract}
Objective: This study investigated the potential use of sawdust of Daniellia oliveri (African Copaiba Balsam Tree), Rice husk and Groundnut shells to make briquettes for energy generation.

Methodology and Result: Doughnut shaped briquettes were produced from three biomass materials at 15\%, $25 \%$, and $35 \%$ level of starch binder in binary and tertiary combinations. Density, Shatter index and Combustion properties of the briquettes were investigated. The compressed density of Daniellia oliveri + Groundnut briquettes was highly significant $(P<0.01)$ at $2.32 \mathrm{~g} / \mathrm{cm}^{3}$. The relaxed density was highly significant $(P<0.01)$ among the biomass materials and binder levels. Daniellia + Groundnut briquettes recorded the highest relaxed density of $2.46 \mathrm{~g} / \mathrm{cm}^{3}$ at $25 \%$ starch binder. Daniellia + Groundnut briquettes recorded the highest shatter resistance of 90.4 . The specific heat of combustion of briquettes ranged from $4455.0 \mathrm{Kcal} / \mathrm{kg}$ to $4734.0 \mathrm{Kcal} / \mathrm{kg}$.

Conclusion and Application of Results: The relative high heating values of the briquettes biomass materials indicate that they can be a very good alternative source of energy for domestic cooking. It is therefore recommended that sawdust of Daniellia oliveri, Rice husk and Groundnut shells that are usually discarded as waste in Nigeria could be converted to briquettes, which will serve as alternative source of energy for domestic cooking.
\end{abstract}

\section{INTRODUCTION}

Globally, 140 billion metric tons of biomass is generated every year from agriculture. This volume of biomass can be converted to an enormous amount of energy and raw materials (Jekayinfa and Scholz, 2009). Renewable energy sources are been sought for domestic cooking in developing countries because their non-renewable counterpart such as kerosene, LPG, are expensive. In addition, the high cost of non-renewable energy sources has made people to start deviating to the use of renewable energy sources for domestic cooking. The use of biomass fuel such as composite sawdust briquette has been proposed to be a good source of renewable energy for domestic cooking (Kuti and Adegoke 2008). This is because sawdust, i.e., the chief raw material in the production of composite sawdust briquette is readily available in large quantities as wastes in majority of the wood processing industries. It has been proposed that the conversion of sawdust wastes through briquetting process will go a long way in reducing waste disposal problems in majority of the wood processing industries. Furthermore, deforestation, which promotes pollution, will be drastically reduced if the use of sawdust waste is enhanced.

Energy availability in the rural as well as urban areas of Nigeria is fast becoming a great challenge with the high cost of cooking gas and kerosene and environmental problems associated with firewood (Oladeji, 2011a). A large number of waste products (maize, sorghum, and millet stalks; groundnut and maize husks) are generated in rural areas both on 
the farm and from household activities. Most of these wastes are mainly deposited on the farm or burnt with all the ecological problems associated with their disposal methods (Jekayinfa and Omisakin, 2005; Oladeji, 2011b). However, studies had revealed that, most of these wastes have been found to represent valuable energy (Jekayinfa and Scholz, 2009). The realization that deforestation and wood fuel shortages are likely to become pressing problems in many countries has turned attention to other types of biomass fuel. Agricultural residues are, in principle, one of the most important of these. They arise in large volumes and in the rural areas, which are often subject to some of the worst pressures of wood shortage (Eriksson and Prior 1990). If one or more efficient method of using the abundant agricultural and wood residues could be developed on a large cale, the energy situation could be sustainable and the deforestation problem could be controlled. The lack of capital among most households in the rural communities makes it difficult to move from either firewood or charcoal, to a more advanced energy sources where small initial capital investment can be used. Hence, the substitute of these fuels requires a minimal capital investment, be as cheap and accessible as charcoal and firewood and at the same time, be environmentally sustainable. Hence, the need for

\section{MATERIALS AND METHODS}

Study area: The experimental process of briquette production was done at the Mechanical Engineering and Food Science Technology Laboratories of the Federal University of Agriculture, Makurdi, Benue State of Nigeria. The groundnut shells, rice husk and sawdust of Daniellia oliveri were collected in Makurdi area of Benue state where the materials are produced in large quantities. Groundnut shells were air-dried and ground using a grinding machine. The three-biomass residues were sieved to uniform sizes of $1.71 \mathrm{~mm}$, labelled and stored for briquetting.

Binder ratio: Cassava starch was used as binder for the briquettes. Three starch ratios notably $15 \%, 25 \%$, $35 \%$ of the weight of sample as conducted by Sotannde et al. (2010) was used to determine the effect of binder concentration on physical and chemical characteristics of briquettes produced from groundnut shells, rice husk and Daniellia oliveri biomass materials.

Briquette production and quality evaluation: Groundnut shells, rice husk and sawdust of Daniella oliveri were used to produce briquettes at binary and tertiary combinations using doughnut shaped moulds. One hundred $(100 \mathrm{~g})$ of dried ground and uniformly briquetting of agricultural residues and sawdust to serve as a cheap and affordable alternative fuel energy for domestic application. The abundantly available agricultural and wood residues can efficiently be used for resolving energy problems to a significant extent by adopting proper measures. Olorunnisola (2002) stated that biomass processing technologies like biomass combustion, gasification and briquetting/pelletizing are in place with potential viable local markets. He affirmed that it was evident that none of these alternatives can compete with the low capital investment that is required in briquetting technology. Several kinds of agricultural residues can be utilized properly by identifying loose residues to produce a compact product of different sizes. Briquetting is essentially a mechanical process requiring investment in equipment and training to ensure a product of reasonable quality that will perform the task for which it is intended. Russell, (1997) considered that briquetting is often seen as a relatively high-cost high-pressure technology, and that it is possible to use a low-cost low-pressure technique to produce acceptable briquettes. For rural communities the most suitable briquetting methods are those, which are based on available waste and building materials.

sieved sampled was mixed with cassava starch until a uniform mixture was obtained. The proportions of sample: binder ratio was 100:15; 100:25, 100:35 (Sotannde, et al. 2010).The sample-binder mixture was hand-fed into the steel mould for doughnut briquettes and covered at both ends with the disk. The sample binder mix inside mould was then placed under the hydraulic press and compacted at the pressure of $10.70 \mathrm{~kg} . \mathrm{cm}-2$, and kept under pressure for duel time of 5 minutes. At each level of binder, 15 replicates were produced. The diameter of the briquettes was thereafter taken at two different points with aid of digital callipers while the weight and thickness was recorded immediately. The briquettes were produced at binary and tertiary combinations using Groundnut shells Rice husk and Daniellia oliveri in equal proportion of mixtures as used by Tembe, et al. (2011) on briquettes produced from groundnut shells and rice husk as follows:

- $\quad$ Groundnut shells and Rice husk; 50:50.

- $\quad$ Groundnut shells and Daniellia oliveri; 50:50.

- Groundnut shells, Rice husk and Daniellia oliveri 33.3: 33.3: 33.3.

Determination of physical properties: 
Density: Three briquettes were randomly selected from each production batch for evaluation of physical properties. The mean compressed density of the briquettes was determined immediately after removal from the mould as a ratio of measured weight to calculated volume (Olorunnisola, 2007). The weights of produced briquettes were determined using a digital weighing balance, while the average diameters and heights of the briquettes were taken at 2 different positions using callipers to determine the volume. The volume of the doughnut shaped briquettes was determined by subtracting the outer volume from the inner volume to obtain the actual volume of the briquettes. The compressed and relaxed densities of the briquettes were determined at 0 minutes, 30 minutes, 1 hour, 24 hours and 7 days using the die dimensions and ASTM, (2004) standard method of determining densities. Density was determined for each briquette as ratio of briquette weight to volume.

\section{Density $=$ Weight of Briquettes Volume of briquette}

Shattered Index: The durability of the briquettes was determined in accordance with the Shattered index described by Suparin et al. (2008).This involved dropping the briquette samples repeatedly from a specific height of $1.5 \mathrm{~m}$ onto a solid base. The fraction of the briquette retained was used as an index of briquette breakability. The percentage weight loss of briquettes was expressed as a percentage of the initial mass of the material remaining on the solid base, while the shatter resistance was obtained by subtracting the percentage weight loss from 100 (Ghorpade, 2006 and Sengar, et al. 2012),

Percentage weight loss $=$

Initial weight before shatter - Weight of shattering

Initial weight of briquette before shattering

Shatter resistance $=100$ - Percentage weight loss

Combustion properties determination: The following combustion properties were used to determine the

\section{RESULT AND DISCUSSION}

Effect of Type of material on Density of briquettes: The type of briquette material had highly significant effect $(P<0.01)$ on compressed density (density immediately after compression at 0 minutes). Daniellia + $\mathrm{G} /$ nut briquettes recorded the highest compressed density of $2.32 \mathrm{~g} / \mathrm{cm}^{3}$ which was significantly higher than Daniellia + Rice husk briquettes with compressed density of $2.19 \mathrm{~g} / \mathrm{cm}^{3}$ (Table 1). The lowest compressed density of $2.19 \mathrm{~g} / \mathrm{cm}^{3}$ for Daniellia + Rice briquettes was higher than $0.92 \mathrm{~g} / \mathrm{cm}^{3}$ obtained by Lensu, (2005) in his work on compacted straw particles. High values of compressed density could be linked to moisture present in the starch, which increased the mass per unit volume suitability of briquettes as cooking fuels, the combustion properties include the percentage Ash content, percentage Volatile matter, percentage fixed carbon, the heating value and $\%$ moisture content.

Percentage Moisture Content (\% MC): Percentage $\mathrm{MC}$ was determined by measuring $2 \mathrm{~g}$ of pulverized briquettes into a crucible (w1). The content was dried in an over at $110^{\circ} \mathrm{C}-120^{\circ} \mathrm{C}$ for $2 \mathrm{hrs}$ to obtain over dry weight (w2). Moisture Content was then calculated according to Davies and Abolude (2013) as:

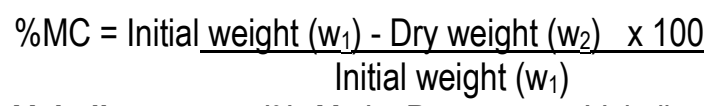

Volatile matter $(\% \mathrm{Vm})$ : Percentage Volatile matter was determined keeping the substance in crucible with oven dry weight (w2) in the furnace for $10 \mathrm{mins}$ at $400^{\circ} \mathrm{C}$ to obtain weight (w3) after which the volatile matter in it have escaped. The method was used by (Emerhi, 2011). This was used in calculating percentage volatile matter thus:

$\% \mathrm{VM}=$

Oven dry weight $\left(w_{2}\right)$-Weight of sample $\left(w_{3}\right) \times 100$ Oven dry weight $\left(w_{2}\right)$

Ash content ash): In determination of percentage ash, $2 \mathrm{~g}$ of oven dried pulverized briquettes were weighed in a crucible (w2), this was placed in the furnace for $3 \mathrm{hrs}$ at $600^{\circ} \mathrm{c}$ to obtain the ash weight (w4). Percentage ash content $\%$ Ash contents was calculated as

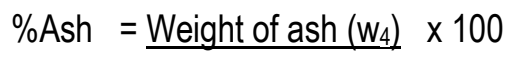
Dry weight $\left(\mathrm{w}_{2}\right)$

Fixed carbon ( $\% \mathrm{fc}$ ): this was calculated by subtracting the sum of $\%$ volatile matter and $\%$ ash content from $100 . \%$ f c $=100 \%$ - (\% Vm +\% Ash)

Specific heat of combustion (HC): Specific heat of combustion $(\mathrm{HC})$ was calculated using the formula (Carre, et al. 1981):

$\mathrm{HC}=0.35[(147.6 \mathrm{x} \mathrm{fc})+(144 \mathrm{x} \mathrm{vm})+\%$ Ash $] \mathrm{Kcal} / \mathrm{kg}$.

The data collected from sample tests were subjected to analysis of variance using the factorial designed in Completely Randomized Design (CRD).

of the briquettes. The relaxed density (density at any point of drying from 30 minutes -7 days) was significantly high $(P<0.01)$ for all briquette samples as presented in Table 1 . The density values showed a progressive decline from $2.34 \mathrm{~g} / \mathrm{cm}^{3}$ for Daniellia + $\mathrm{G} /$ nut briquettes at 30 minutes to $1.42 \mathrm{~g} / \mathrm{cm}^{3}$ at 7 days of drying. A similar trend was observed for Daniellia + Rice briquettes, which declined from $2.14 \mathrm{~g} / \mathrm{cm}^{3}$ to $1.44 \mathrm{~g} / \mathrm{cm} 3$ at 30 minutes and 7 days respectively (Table 1). However the relaxed density of Daniellia + Rice + $\mathrm{G} /$ nut briquettes showed a slight increase from $2.13 \mathrm{~g} / \mathrm{cm}^{3}$ at 30 minutes to $2.28 \mathrm{~g} / \mathrm{cm}^{3}$ at 1 hour before reducing to $1.58 \mathrm{~g} / \mathrm{cm}^{3}$ in 7 days (Table 1). The relaxed 
density of Daniellia + Rice + G/nut briquettes was still higher than that of compacted peat at $1.11-1.20 \mathrm{~g} / \mathrm{cm}^{3}$ as recorded by Lensu (2005), and higher than Obi, et al. (2013) who recorded the relaxed density of $0.7269 \mathrm{~g} / \mathrm{cm}^{3}$. The variation in relaxed density from 30 minutes to 7 days of the briquette samples could be linked to the impact of moisture loss, which reduces the mass per unit volume of the briquettes but enhances physical properties of briquettes as reported by Obi, et al. (2013).

Table 1: Density of Briquette materials

\begin{tabular}{|l|c|c|c|c|c|}
\hline Sample & $\mathbf{0}$ min & 30mins & 1hour & 24hours & $\mathbf{7}$ days \\
\hline Daniellia +G/nut & 2.32 & 2.34 & 2.25 & 2.01 & 1.42 \\
\hline Daniellia + Rice & 2.19 & 2.14 & 2.13 & 1.78 & 1.44 \\
\hline Daniellia + Rice+ G/nut & 2.31 & 2.13 & 2.28 & 1.90 & 1.58 \\
\hline LSD & 0.086 & 0.043 & 0.089 & 0.078 & 0.042 \\
\hline
\end{tabular}

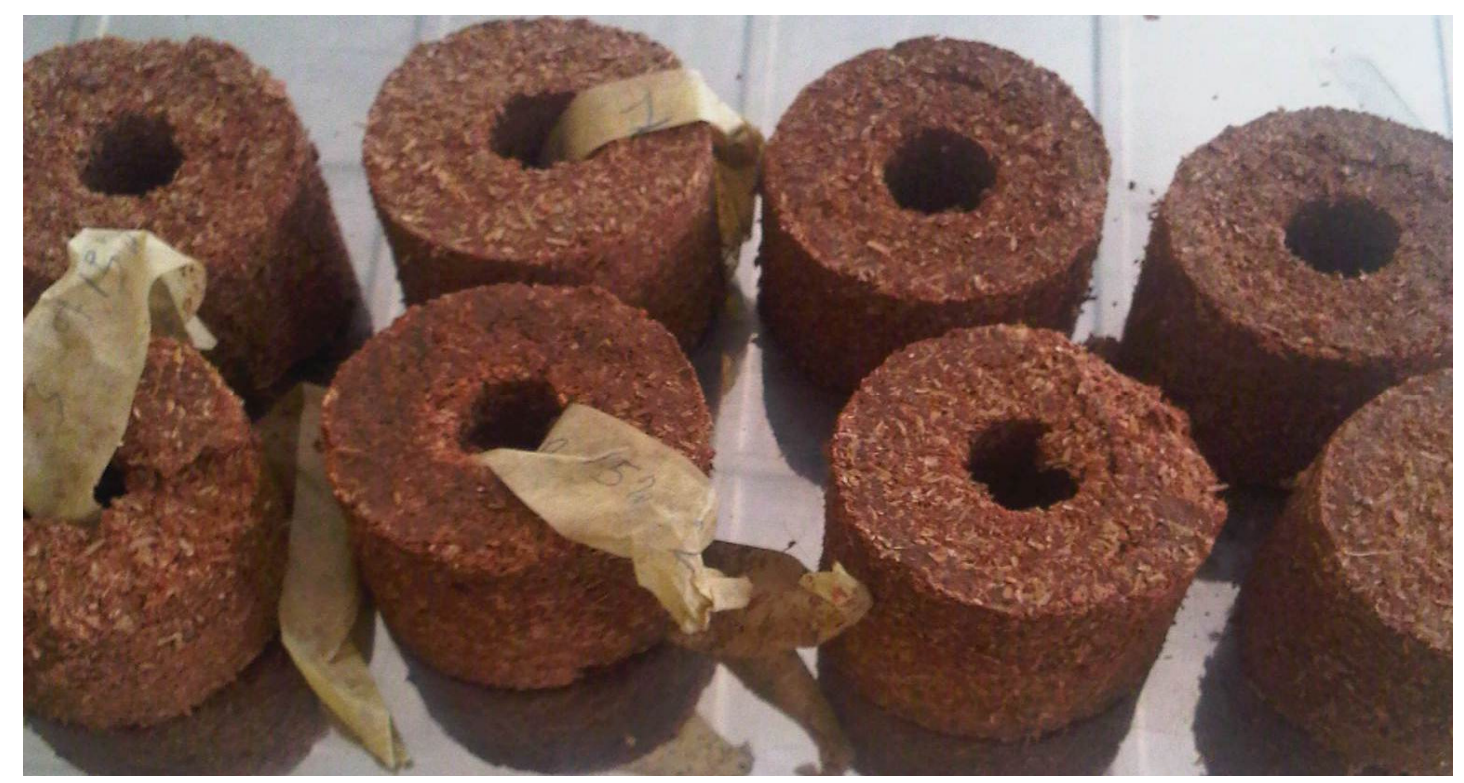

Plate 1: Doughnut shaped briquettes

Effect of Binder levels on Density of Briquettes: Different binder levels of starch did not cause significant differences $(P>0.05)$ on compressed density of briquettes at $0 \mathrm{~min}$. However, the relaxed density of briquettes at $25 \%$ binder level was constant at $30 \mathrm{~min}$ and 1 hour and decreased rapidly to $1.51 \mathrm{~g} / \mathrm{cm}^{3}$ in 7 days (Table 2). The relaxed density at $15 \%$ binder level showed a progressive decline from $2.21 \mathrm{~g} / \mathrm{cm}^{3}$ at 30 minutes to $1.44 \mathrm{~g} / \mathrm{cm}^{3}$ in 7 days and the relaxed density
$35 \%$ binder recorded $2.15 \mathrm{~g} / \mathrm{cm}^{3}$ in 30 minutes and increased to $2.28 \mathrm{~g} / \mathrm{cm}^{3}$ in 1 hour before decreasing to $1.41 \mathrm{~g} / \mathrm{cm}^{3}$ in 7 days. The relaxed density of $1.51 \mathrm{~g} / \mathrm{cm}^{3}$ at $25 \%$ binder was higher than $1.10 \mathrm{~g} / \mathrm{cm}^{3}$ for sawdust briquette, reported by Singh (2009). The result indicates that $25 \%$ binder level is the optimum binder concentration for briquette production, which agrees with Tembe, et al. (2011).

Table 2: Effect of Binder level on Density of Briquettes

\begin{tabular}{|l|c|c|c|c|c|}
\hline & \multicolumn{5}{|c|}{ Density $\left(\mathrm{g} / \mathrm{cm}^{3}\right)$} \\
\hline Binder levels & Omin & 30mins & 1hour & 24hours & 7days \\
\hline $15 \%$ & 2.24 & 2.21 & 2.15 & 1.83 & 1.44 \\
\hline $25 \%$ & 2.33 & 2.23 & 2.23 & 1.90 & 1.51 \\
\hline $35 \%$ & 2.25 & 2.15 & 2.28 & 1.96 & 1.41 \\
\hline LSD & NS & 0.043 & 0.089 & 0.078 & 0.042 \\
\hline
\end{tabular}

Weight loss and Shatter resistance of briquettes: The Weight loss of briquettes was highly significant $(P<0.01)$. Daniellia + Rice briquettes recorded the highest weight loss of $34.6 \%$, which was significantly higher than Daniellia + Groundnut with weight loss of
9.7\% (Table 3). The shatter resistance was not significant $(P>0.12)$ for all the briquettes in (Table 3) Daniellia + Groundnut briquettes recorded the highest shatter resistance of $90.4 \%$, which was higher than Daniellia + Rice briquettes with shatter resistance of 
$72.4 \%$. The high shatter resistance and low weight loss

and resistance to handling stresses.

of Daniellia $+\mathrm{G} /$ nut briquettes indicates high stability

Table 3: Weight Loss and Shatter resistance of briquettes

\begin{tabular}{|l|l|l|}
\hline Sample & Weight loss\% & Shatter resistance\% \\
\hline Daniellia + G/nut & 9.7 & 90.4 \\
\hline Daniellia + Rice & 34.6 & 72.4 \\
\hline Daniellia + Rice+ G/nut & 12.8 & 87.2 \\
\hline LSD & 12.82 & NS \\
\hline
\end{tabular}

Effect of Binder level on Weight loss and Shatter resistance of Briquettes: The weight loss of briquettes due to variation in binder level was highly significant $(P<$ 0.01) (Table 4). Briquettes at $15 \%$ binder levels recorded the highest weight loss of $39.7 \%$ while $35 \%$ binder levels recorded the lowest weight loss of $0.9 \%$.
The shatter resistance was significant $(P<0.05)$ with $35 \%$ binder level recording the highest shatter resistance of $99.1 \%$. This implies that briquettes produced with higher concentration of starch binders are more durable and resistant to handling stresses.

Table 4: Effect of weight loss at Binder levels of Briquettes

\begin{tabular}{|l|c|c|}
\hline Binder levels & Weight loss $\%$ & Shatter resistance\% \\
\hline $15 \%$ & 39.7 & 67.3 \\
\hline $25 \%$ & 16.5 & 83.5 \\
\hline $35 \%$ & 0.9 & 99.1 \\
\hline LSD & 12.82 & 18.31 \\
\hline
\end{tabular}

Effect of Type of Materials on Combustion properties of Briquettes: Percentage Ash content: The percentage Ash content of briquettes was highly significant $(P<0.01)$, Daniellia + Rice $+G /$ nut briquettes recorded the highest Ash content of $11.27 \%$ (Table 5). The ash content in briquettes normally cause increase in combustion remnant in the form of ash which lowers the heating value of briquettes, low ash content offer higher heating value for briquettes (Obi et al. 2013). The Fixed carbon of briquettes was also significantly high $(P<0.01)$. Daniellia + Rice + G/nut briquettes recorded the highest Fixed carbon (Fc \%) of $32.11 \%$ while Daniellia $+\mathrm{G} /$ nut briquettes recorded fixed carbon of $24.26 \%$ (Table 5). The Heat of combustion of briquettes was also highly significant $(P<0.01)$. Daniellia $+G /$ nut briquettes recorded the highest heat of combustion of $4710.0(\mathrm{Kcal} / \mathrm{kg})$ which was higher than $4516.0(\mathrm{Kcal} / \mathrm{kg})$ from Daniellia + Rice + G/nut (Table5). This indicates that any of the three (3) briquettes combinations could serve as an efficient briquette fuel since the heat of combustion values fall within the same range. The result is lower than $5210 \mathrm{kcal} / \mathrm{kg}$ for Anoeissus leiocaarpa and $4908 \mathrm{kcal} / \mathrm{kg}$ for Gmelina arborea as reported by Egbewole et al. (2009) These values are however higher than $33.37 \mathrm{MJ}^{\mathrm{kg}}{ }^{-1}$ recorded by Obi et al. (2013) in their work on briquetting machine. The percentage moisture content $(\mathrm{MC} \%)$ of briquettes was also highly significant $(P<0.01)$, Daniellia $+G /$ nut briquettes recorded the highest moisture content of $12.94 \%$ while Daniellia + Rice + G/nut briquettes recorded 9.83\% moisture content (Table 5). The percentage moisture content is within operating limits of 8-12\% (Eriksson and Prior, 1990). The percentage Volatile matter ( $\mathrm{Vm} \%)$ of briquettes was also highly significant $(P<0.01)$, Daniellia + G/nut briquettes recorded the highest percentage Volatile matter of $68.54 \%$ while Daniellia + Rice $+\mathrm{G} /$ nut briquettes recorded $\mathrm{Vm} \%$ of $56.62 \%$ (Table 5). The percentage volatile matter of the briquettes was higher than normal value of $20 \%$ as reported by Ivanon et al. (2003).

Table 5: Combustion properties of Briquette materials

\begin{tabular}{|l|l|l|l|l|l|}
\hline Briquette Samples & Ash\% & Fc\% & Hc(Kcal/kg) & MC\% & VM\% \\
\hline Daniellia + G/nut & 7.20 & 24.26 & 4710.0 & 12.94 & 68.54 \\
\hline Daniellia + Rice & 9.91 & 25.55 & 4610.0 & 10.39 & 64.53 \\
\hline Daniellia + Rice + G/nut & 11.27 & 32.11 & 4516.0 & 9.83 & 56.62 \\
\hline \multicolumn{1}{|c|}{ LSD } & 0.48 & 0.62 & 51.7 & 0.39 & 0.73 \\
\hline
\end{tabular}


Effect of Binder levels on Combustion properties of Briquettes: The Ash content of briquettes was highly significant $(P<0.01)$ on binder levels. $15 \%$ binder level recorded the highest ash content of $10.46 \%$ while $35 \%$ binder produced the lowest percentage ash content $8.43 \%$ (Table 6). Low ash content offers higher heating value for briquettes (Obi et al. 2013). The percentage Fixed carbon was also highly significant $(P<0.01)$ on binder levels with $35 \%$ recording the highest fixed carbon of $28.34 \%$ (Table 6). Specific Heat of combustion was significant $(P<0.01)$ among binder levels; $35 \%$ binder level produced the highest heat of combustion of $4653.0 \mathrm{Kcal} / \mathrm{kg}$ (Table 6). Moisture content of briquettes was significant $(P<0.05)$ among binder levels, $35 \%$ binder levels recorded the highest moisture content of $11.33 \%$ while $25 \%$ binder level recorded $10.83 \%$ moisture content (Table 6). The percentage moisture content of briquettes fall within accepted levels of 8-12\% (Eriksson and Prior, 1990).The Volatile matter of briquettes was significant $(P<0.01)$ among binder levels, $15 \%$ binder recorded the highest Volatile matter of $63.71 \%$ followed by $25 \%$ binder level of starch which was $62.76 \%$ (Table 6). The percentage Volatile matter is above the normal value of $20 \%$ by reported Ivanon et al. (2003).

Table 6: Combustion properties of Briquettes at varying binder levels

\begin{tabular}{|l|l|l|l|l|l|}
\hline Binder levels & Ash $\%$ & Fc\% & Hc(Kcal/kg) & MC\% & VM\% \\
\hline $15 \%$ & 10.46 & 25.84 & 4577 & 11.00 & 63.71 \\
\hline $25 \%$ & 9.41 & 27.75 & 4606 & 10.83 & 62.76 \\
\hline $35 \%$ & 8.43 & 28.34 & 4653 & 11.33 & 63.23 \\
\hline LSD & 0.48 & 0.62 & 51.7 & 0.39 & 0.73 \\
\hline
\end{tabular}

\section{CONCLUSION AND RECOMMENDATION}

The study has shown that briquettes produced from binary and tertiary combinations of Daniellia oliveri, Rice husk and Groundnut shells produced high heating values ranging from $4710.0 \mathrm{Kcal} / \mathrm{kg}$ to $4516.0 \mathrm{Kcal} /$ which was higher than that of Elaigwu, et al (2010) who got $3215.25-4010 \mathrm{Kcal} / \mathrm{kg}$ in his research on agricultural waste briquettes. The result was however lower than $5210 \mathrm{kcal} / \mathrm{kg}$ for Anoeissus leiocaarpa (African birch) and $4908 \mathrm{kcal} / \mathrm{kg}$ for Gmelina arborea (gamhar, gumhar, gamari, beechwood, goomar teak, Kashmir tree).This makes the combination of briquettes from sawdust of Daniellia oliveri and residues from rice husk and

\section{REFERENCES}

ASTM Standard E711-87, (2004). Standard test method for gross calorific values of refuse- derived fuel by the bomb calorimeter Annual book of ASTM Standard 11:04 ASTM International http// www.astm.info/standard/E711.htm

Carre, J; Lacrosse, L and Schenkel, Y. (1981) Technical and economic constraints of Biomass briquetting, European symposium on soft energy sources at the local level Greece, Naxos, August 2009-September 2,1981.

Davies, R.M. and Abolude, D.S. (2013) Journal of Scientific Research and Reports 2(1): 11-120, 2013, Article no JSRR 2013.09.

Elaigwu, V., Adetogun, A.C and Tembe, E. (2010): The combustion properties of Briquettes produced Groundnut Shells and Rice Husk. Pp 14-20.

Eriksson, S. and Prior, M. (1990): The briquetting of Agricultural Wastes for fuel. FAO. Publication (1990). groundnut shell a good substitute for fuel. Briquettes produced at thirty five (35\%) starch binder level recorded the highest combustion properties. It is therefore recommended that briquette production using sawdust and agricultural residues of Daniellia oliveri, Rice husk and Groundnut shells be done at binary and tertiary levels because of high heating value from the combinations. Starch binder level of $35 \%$ is also recommended for briquette production from the combinations because of the relative stability and high combustion properties of produced briquettes.

Emerhi E.A, (2011) Physical and Combustion Properties of Briquettes Produced from sawdust of three hard Wood Species and Different Organic Binders, Advances in Applied Science Research, 2(6): 236-246.

Ghorpade, S.S; Moule, A.P. (2006). Performance Evaluation of Deoiled Cashew Shell waste for fuel properties in Briquetted form. B. Tech. Thesis (unpub.), Dapoli 15.

Jekayinfa, S.O. and Omisakin O.O. (2005). The energy potentials of some agricultural wastes as local fuel materials in Nigeria 2005 Agricultural Engineering International, the CIGR E-Journal of Scientific Research and Development, Vol. III, Manuscript EE 05 003:10.

Jekayinfa, S.O. and Scholz V. (2009). Potential Availability of Energetically Usable Crop Residues in Nigeria Energy Sources 2009 Part A, Vol. 31: 687-697. 
Ivavov, I.P and Kuznetsovv B. (2003): Manufacture of Briquetted and Granulated fuels from lignite with Biobinders and Heated Die. Chemistry for sustainable development, 11: 487-852p.

Kuti, O.A.; and Adegoke, C.O. (2008). Comparative performance of composite sawdust briquette with kerosene fuel under domestic cooking conditions. AU J.T. 12: 57-61.

Lardinois, I and Klundert, A. (1993). Organic Waste Options for Small - Scale Resource Recovery. Waste Consultants. The Netherlands.

Lensu, T. (2005). Quality guidelines for fuel peat preparation started. In: Newsletter 2 on standards for bioenergy in the Baltic Sea Area. - March 2005. - Nordisk Innovation Centre. Available at http://www.nordicinnovation.net/_img/newslette r2_final.pdf

Obi, O.F; Akubo, C.O; Okonkwo, W.I. (2013) Development of an Appropriate Briquetting Machine for use in Rural Communities. International Journal of Engineering and Advanced Technology (IJEAT) ISSN 22498958, Volume 2.

Oladeji J.T. (2011a). Pyrolytic Conversion of Cow Dung into Medium-Grade Biomass Fuels International Journal of Pure and Applied Sciences 2011a Volume 4 number 2, pp173178.

Oladeji J.T. (2011b). The Effects of Some Processing Parameters on Physical and Combustion Characteristics of Corncob Briquettes, An Unpublished PhD Thesis of the Department of Mechanical Engineering, Ladoke Akintola University of Technology, Ogbomoso, Nigeria $2011 \mathrm{~b}$.

Olorunnisola, A.O. (2002). Assessment of some critical factors influencing Biofuel Production Systems
Research, Development and Adoption in Nigeria. American Society of Agricultural and Biological Engineers, St Joseph, Michigan.

Olorunnisola, A.O. (2007). Production of fuel briquettes from waste paper and coconut Husk Admixture. Agricultural Engineering International. The CIGR E journal. EE 06006. Vol. IX.

Russell, A. (1997). Using Biomass residue for Energy. Issue 39. Briquetting Agricultural Residues (knowledge Bank). Hedon Household Energy Network.

Sengar S.H, Mohod, A.G; Khandetod Y.P; Patil S.S and Chendake A.D (2012) Performance of Briquetting Machine for Briquette fuel. International Journal of Energy Engineering.

Singh, R.M. Kim, H. Kamide, M. and Sharma, T. (2009) "Biobriquettes-an alternative fuel for Sustainable development". Nepal Journal of Science and Technology. Volume 10, 2009, pp.121-127.

Sotannde, O. A. Oluyege, A. O. and Abah, G. B. (2010) Physical and combustion of charcoal Briquettes and Neem wood Residues, International Agro-Physics 24: 189-194 Journal of Forestry Research.

Suparin C, Suwit S, Prattana K., (2008): Development of fuel briquettes from biomass-lignite blends. Chiang. Mai. J. Sci., 35(1):43-50.

Tembe, E.T; Adetogun, E.C and Elaigwu, V.O (2011): Comparative analysis of Combustion properties of Briquettes produced from Groundnut shell and Rice husk. Proceedings of the $34^{\text {th }}$ Annual Conference of the Forestry Association of Nigeria held in Oshogbo, Osun State Nigeria. 